\title{
Consistent Inequality across Germany? Exploring Spatial Heterogeneity in the Unequal Distribution of Air Pollution
}

\author{
Tobias Rüttenauer ${ }^{\mathrm{a}}$ and Henning Best ${ }^{\mathrm{b}}$ \\ ${ }^{a}$ University of Oxford, Nuffield College, New Road, Oxford OX1 1NF, United Kingdom \\ b University of Kaiserslautern, Department of Social Sciences, Erwin-Schrödinger-Str. 57, \\ 67663 Kaiserslautern, Germany
}

\begin{abstract}
The topic of environmental inequality, in general describing the unequal distribution of environmental pollution across different social groups, has received increasing attention in Germany and other European countries during the past decade. Though research points towards a disadvantage of minorities in Europe, conclusions regarding the extent of this disadvantage vary across studies. In this contribution, we thus examine whether the extent of environmental inequality depends on the measure of pollution and the spatial scale. We connect spatially aggregated data of the 2011 German census to geographical information of industrial facilities and pollution estimates of German-wide diffusion models. We then use spatial regression models to identify the disadvantage of foreign minorities across these measures. Furthermore, we perform geographically weighted regressions to scrutinize the role of the spatial scale and location. We find that the pollution minority gap is stronger for estimates based on industrial facilities than it is for general pollution models, though there is a consistent disadvantage of minorities within municipalities. Furthermore, we demonstrate that there is strong heterogeneity in the association between the share of foreign minorities and air pollution according to the spatial scale and location of the research area.
\end{abstract}

\section{KEYWORDS}

Air Pollution; Environmental Inequality; Geographically Weighted Regression; Spatial Heterogeneity; Industrial Facilities

\section{Authors' pre-copy-editing version. Please cite the final chapter:}

Rüttenauer, T., \& Best, H. (2021). Consistent Inequality across Germany? Exploring Spatial Heterogeneity in the Unequal Distribution of Air Pollution. In A. Franzen, S. Mader (Eds.) Research Handbook on Environmental Sociology. Cheltenham: Edward Elgar Publishing. ISBN 9781800370449, http://dx.doi.org/10.4337/9781800370456 


\section{Introduction}

Worldwide, air pollution is estimated to be responsible for 9 million premature deaths per year, thereby accounting for $16 \%$ of all premature deaths (Landrigan et al., 2018). Also in Europe, the European Environment Agency attributes an estimated annual 400,000 premature deaths to air pollution (European Environment Agency, 2019). Despite the serious health impacts, research has also shown that the exposure to pollution can be linked to other social outcomes like education or economic performance (e.g. Persico, 2020). Yet, environmental pollution is not equally distributed across the society and disproportionately affects the poor and minorities. Because of its severe consequences for the population at risk, this unequal distribution of pollution constitutes an important dimension of social inequality.

As one of the first research studies on the topic of environmental inequality, the report of the United Church of Christ - Commission for Racial Justice (1987) demonstrated that minorities and the socio-economically disadvantaged in the United States live disproportionately close to hazardous industrial facilities. Ever since, environmental inequality has been on the agenda of social science research in the US (e.g. Anderton, Anderson, Oakes, \& Fraser, 1994; Been, 1994; Bryant \& Mohai, 1992; Bullard, 1990). Within the past decades, various studies (for an overview e.g. Banzhaf, Ma, \& Timmins, 2019a; Mohai \& Saha, 2015) have documented a persistently high pollution disadvantage of minority groups and the economically disadvantaged (Colmer, Hardman, Shimshack, \& Voorheis, 2020). As Mohai, Pellow, and Roberts (2009, p. 406) put it: 'Today, hundreds of studies conclude that, in general, ethnic minorities, indigenous persons, people of color, and low-income communities confront a higher burden of environmental exposure from air, water, and soil pollution from industrialization'.

Also in Europe, environmental inequality research has gained increasing interest over the past years. There are now several empirical studies documenting the unequal distribution of environmental hazards in Germany and other European countries (e.g. Best \& Rüttenauer, 2018; Diekmann \& Meyer, 2010; Flacke, Schüle, Köckler, \& Bolte, 2016; Glatter-Götz, Mohai, Haas, \& Plutzar, 2019; Kabisch \& Haase, 2014; Kohlhuber, Mielck, Weiland, \& Bolte, 2006; Padilla et al., 2014; Raddatz \& Mennis, 2013; Rüttenauer, 2018b, 2019a). Still, as we will elaborate in detail below, results tend to disagree on the extent of environmental inequality in Europe. While some studies report substantial inequalities, others conclude that the social gradient in pollution is negligible. A possible reason for the inconsistent results in previous research might be the use of distinct types of pollution measures and the focus on different geographical areas. While some studies focus on industrial facilities, others use public green spaces or general air pollution as measures of environmental quality. Moreover, studies vary in geographical location and the spatial scale, ranging from case studies in single cities to countrywide comparisons. Weigand, Wurm, Dech, and Taubenböck (2019), for instance, provide a comprehensive overview of varying spatial scales and measures used 
in environmental inequality research, and also discuss potential problems of commonly used data types.

In this study, we thus contribute to the current state of research in two ways. First, we investigate if conclusions on environmental inequality depend on the measure of pollution. Second, we follow an explorative approach to assess if the extent of environmental inequality changes with different geographical scales and locations across Germany. For this purpose, we use aggregated census data and two sources of pollution: point sources of industrial facilities and pollution estimates from diffusion models. Thus, we are able to calculate the correlation between the share of minorities and air pollution based on two different ways of measuring pollution. Furthermore, we employ geographically weighted regression techniques to calculate the extent of environmental inequality for a range of different locations in Germany and for various geographical scales.

In this chapter we proceed as follows. We first provide an overview on potential theoretical explanations for the disproportionate exposure of disadvantaged groups to environmental pollution, and subsequently outline the current state of research in Europe. We then shortly describe the data which follows a previous study (Rüttenauer, 2018b), but extends previous analyses by additional pollution measures. We then compare the extent of environmental inequality across the distinct measures of pollution, and subsequently investigate the geographical heterogeneity in environmental inequality.

\section{Theoretical background ${ }^{1}$}

The environmental inequality literature distinguishes between two main causes for the unequal distribution of environmental pollution: selective siting and selective migration (e.g. Banzhaf et al., 2019a; Banzhaf, Ma, \& Timmins, 2019b; Been \& Gupta, 1997; Crowder \& Downey, 2010; Hamilton, 1995; Sieg, Smith, Banzhaf, \& Walsh, 2004). According to selective siting, industrial facilities are assumed to be sited in or close to areas with a high proportion of minorities and low-income households. The argument of selective migration, in contrast, states that minorities and low-income households have different likelihoods of escaping from and moving into polluted areas. Accordingly, one of the main concerns in environmental inequality research is the question of "which came first?' (Pastor, Sadd, \& Hipp, 2001). The following sections will outline both theoretical arguments in more detail.

\section{1. $\quad$ Selective siting}

The selective siting argument claims that hazardous facilities are disproportionately sited in neighbourhoods that already face a high proportion of minorities or low-income households (Been \& Gupta, 1997; Mohai \& Saha, 2015; Pastor et al., 2001; Saha \& Mohai, 2005; Wolverton, 2009). Three sub-mechanisms might be at work here.

${ }^{1}$ This section is based on a more extensive theoretical discussion in Rüttenauer (2018a). 
First, selective siting might be the results of taste-based discrimination. If decision makers belong predominantly to the majority group and are aware of the danger or the burden of industrial facilities, they might want to externalise unwanted facilities onto minority groups, while protecting members of their own group (Hamilton, 1995).

Second, the market explanation assumes that companies seek to minimise their land and housing costs when locating new unwanted facilities. Because of lower land prices and housing costs, low-income regions are seen as an attractive siting location for new facilities (Downey, 2005; Farber, 1998; Saha \& Mohai, 2005; Wolverton, 2009, 2012). Furthermore, previous research indicates that low-income households have a lower 'willingness to pay' (in the sense of spending less money or not being able to spend money) for environmental goods (Banzhaf, Sidon, \& Walsh, 2012; Franzen \& Vogl, 2013; Liebe, Preisendörfer, \& Meyerhoff, 2010; Meyer \& Liebe, 2010). Potential compensation costs for environmental pollution are thus assumed to be lower in areas with predominantly low-income residents, thus adding to the likelihood of selective siting by profit-maximizing companies (Mohai \& Saha, 2015; Saha \& Mohai, 2005; Wolverton, 2009, 2012). Assuming that minorities are overrepresented in low-income areas, this also adds to their likelihood of receiving industrial disamenities in their residential neighbourhood.

Third, the social and political capital explanation presumes that minorities and lowincome households face a lack of social and political capital. Hence, inhabitants of regions with a high minority share are less likely to organise collective actions against hazardous facilities (Hamilton, 1995; Mohai \& Saha, 2015; Pastor et al., 2001). Low-income households have lower means to influence political decision makers, or to organise legal actions, e.g. to reach a ban of hazardous facilities (Wolverton, 2009). In contrast, high-income residents (often in neighbourhoods with a low minority share), supposedly, are more likely to influence political actors due to their social ties and political engagement or civic activism, and they are able to afford expensive legal proceedings. To avoid protests or legal proceedings, the respective executive decision makers choose the 'path of least political resistance' (Saha \& Mohai, 2005), and selectively locate unwanted facilities in socio-economically disadvantaged neighbourhoods with a higher share of minorities.

\subsection{Selective migration}

The second major explanation of environmental inequality proposes a competing mechanism based on selective migration or sorting processes. In general, this second approach extends the general literature of residential segregation and neighbourhood attainment (e.g. Alba, Logan, Stults, Marzan, \& Zhang, 1999; Crowder, South, \& Chavez, 2006; Logan \& Alba, 1993; South, Huang, Spring, \& Crowder, 2016) by an environmental dimension. The selective migration or sorting hypothesis presumes that the disproportionate exposure of disadvantaged citizens stems from selective migration processes into 
and out of polluted areas (Banzhaf \& McCormick, 2012; Banzhaf \& Walsh, 2008; Crowder \& Downey, 2010; Mohai \& Saha, 2015; Pais, Crowder, \& Downey, 2014; Sieg et al., 2004), thus assuming the opposite temporal order than the first set of mechanisms. Again, three different sub-mechanisms support this theory.

First, the 'racial residential discrimination thesis' states that minorities are steered into polluted areas because of discriminatory barriers on the housing market. On the one hand, housing agents or property owners may fear declining demand and housing prices due to minority in-migration. For instance, research has shown that the minority share is associated with the perception of neighbourhood crime rates above the objective crime rate (Massey \& Denton, 1993; Semyonov, Grodzeisky, \& Glikman, 2012). Hence, housing agents or landlords may prefer renters belonging to the majority group and discriminate against minority applicants (Turner \& Ross, 2005; Yinger, 1986). Even though this explanation is based on housing discrimination against racial minorities in the US, recent research shows that ethnic minorities in Europe and Germany experience comparable levels of discrimination (Auspurg, Schneck, \& Hinz, 2019). On the other hand, housing agents may also spuriously anticipate that minorities have lower preferences for high environmental quality and thus restrict the respective housing offers to a subset of objects with lower quality (Ondrich, Ross, \& Yinger, 2003; Turner \& Ross, 2005). This explanation holds that the selective sorting patterns are a direct consequence of the minority status or race, and are independent of socio-economic resources. Nevertheless, Logan and Alba (1993) also propose a weak and a strong version of place stratification theory, which justifies an interaction between minority status and income, as the extent of experienced discrimination might vary with the income level of applicants.

Second, the 'racial income-inequality thesis' explains minority disadvantages as a function of their lower economic resources. This follows Tiebout's (1956) model of the 'consumer-voter', in which households are assumed to have specific preferences for the provision of public goods and aim to satisfy these preferences by moving between neighbourhoods. Because households prefer a higher environmental quality over a lower one (Bayer, Keohane, \& Timmins, 2009), we expect a higher demand for clean neighbourhoods. Obviously, this also implies higher housing and land prices in areas with high environmental quality (Banzhaf \& McCormick, 2012; Bayer et al., 2009; Farber, 1998). Given that households are 'willing to pay' more for a clean environment as their income rises (Banzhaf et al., 2012; Franzen \& Vogl, 2013; Liebe et al., 2010; Meyer \& Liebe, 2010), high-income households are more likely to move out of low-quality neighbourhoods (selective out-migration) because they can afford to do so. Simultaneously, low-income households are more likely to move into low-quality neighbourhoods (selective in-migration), as these neighbourhoods are more affordable and, thus, more attractive to low-income households. In sum, minorities sort into low-quality neighbourhoods because they cannot afford high-quality areas with high-priced housing opportunities. In contrast to the first explanation, the 'racial 
income-inequality thesis' posits that selective migration or sorting is a function of unequally distributed socio-economic resources among racial or ethnic groups.

A third explanation for residential sorting processes can be based on unequal housing preferences and residential homophily (e.g. Krysan, Couper, Farley, \& Forman, 2009), or the more general course of immigrant assimilation (Logan \& Alba, 1993; Massey \& Denton, 1993). This is not to say that minorities prefer to live in polluted areas. However, there are reasons to assume that minority households have a preference for residential characteristics, which as a side-effect are connected to higher levels of environmental pollution. The ethnic enclave model, for instance, hypothesises that living among co-ethnic peers with similar migration experiences can help to integrate immigrant minorities into the society of the receiving country (Alba et al., 1999; Logan \& Alba, 1993; Logan, Zhang, \& Alba, 2002; Martén, Hainmueller, \& Hangartner, 2019; Winke, 2018). Accordingly, central urban areas with a high share of ethnic minorities can be a favourable environment for cultural assimilation and integration into everyday life. Moreover, these areas offer potential networks for housing and job searches, which seems especially important for immigrant minorities not speaking the language of the receiving country. Likewise, research shows that speaking the language of the host country increases the probability of immigrant households to move from the central city to suburban districts (Alba et al., 1999; Logan et al., 2002). These integration processes thus restrict (immigrant-)minorities' access to suburban or rural areas, which at the same time exhibit much lower levels of pollution. Even though the causal chain is not directly linked to pollution, the fact that ethnic enclaves are often located in central urban areas (Logan et al., 2002; Massey \& Denton, 1988) can induce environmental inequality. This hypothesis is also supported by the finding that urban clusters of highminority areas in central cities at least partly drive the correlation between minority share and pollution in Germany (Rüttenauer, 2018b, 2019a).

\section{Previous Findings in Germany and Europe}

Though environmental inequality research in Europe has received far less attention than in the US, several studies have investigated the unequal distribution of pollution in Europe and Germany (for an overview see e.g. Pasetto, Mattioli, \& Marsili, 2019; Weigand et al., 2019). In most cases, these studies document the disproportionate environmental burden of minority residents and (somewhat less consistent) of socio-economically disadvantaged households. Still, previous results in Europe are characterised by a large plurality of environmental measures, different levels of spatial aggregation, and various empirical research designs (Weigand et al., 2019).

One strand of research in the field, for instance, is mostly concerned with the unequal provision of public green spaces or related land use characteristics. For Germany, Kabisch and Haase (2014) show that foreigners experience a lower provision of public green-space around their place of residence. Similarly, Jünger (2021) finds that migrants 
tend to live in areas with a significantly higher amount of soil sealing in their immediate surrounding. However, based on individual-level GSOEP data, Wüstemann, Kalisch, and Kolbe (2017) derive at rather challenging results: neither migration status nor income are significantly associated with the distance to green spaces. In line with these inconsistencies, research in the UK demonstrates how conclusions vary when considering different measures of green space, like accessibility, area size, or population pressure (Mears, Brindley, Maheswaran, \& Jorgensen, 2019). So, even within this category of environmental measures - green space - results are relatively heterogeneous.

Following the example of earlier environmental inequality studies in the US, also studies in Germany and other European countries have used point locations of industrial facilities provided by the European Pollutant Release and Transfer Register (E-PRTR) to assess environmental inequality. In their case study of Hamburg, Raddatz and Mennis (2013) report a moderate correlation between the minority share and the distance to the nearest industrial facility (a one percentage-point increase in foreigners being associated with a $2 \%$ lower distance to facilities, but with strong spatial multipliers). Based on aggregated census data, Rüttenauer (2018b) finds a relatively strong correlation between the share of foreign nationals and the level of hazardous emissions from industrial sites, which holds nationwide as well as within German municipalities (net of other controls, standardized total impacts of 0.123 and 0.227 respectively). Results also demonstrate that this correlation is stronger within metropolitan areas, and increases for cities with centrally located industrial facilities (Rüttenauer, 2019a). Though only speculative, this somewhat supports the idea that central-city residency of minorities and higher air pollution in inner-cities adds to environmental inequality. Using the same pollution data, Glatter-Götz et al. (2019) also report a relatively strong disadvantage of minorities in Austria: areas with a higher share of immigrant minorities face an increased risk of hosting an industrial facility (9.9\% higher odds with a $1 \%$ higher immigrant share). Moreover, this disadvantage reduces only slightest after controlling for the unemployment rate, education, and the living space per inhabitant, thus questioning the importance of economic resources as a causal pathway of environmental inequality.

Yet other studies have focused on the unequal distribution of general air pollution, which is estimated based on a variety of point and mobile emission sources, and distributed across space by the application of diffusion models. Diekmann and Meyer (2010) provided the first study in Switzerland connecting individual survey data to official estimates of ambient air pollution based on diffusion models. Though they find a moderate disadvantage of the non-native respondents in Switzerland $(17 \%$ of the urban-rural difference in particulate matter), the association with income is negligible ( $0.8 \%$ of the urban-rural difference for 1,000 CHF more income). Similar results seem to apply in France, where Padilla et al. (2014) find only week evidence for an association between deprivation or the share of immigrants and inner-city nitrogen dioxide $\left(\mathrm{NO}_{2}\right)$ concentrations (significant in $3 / 4$ and $2 / 4$ of the cities respectively). For the city of Dortmund, Flacke et al. (2016) identify a moderate bivariate correlation 
between socioeconomic disadvantage and $\mathrm{NO}_{2}$ as well as $\mathrm{PM}_{10}$ on the neighbourhood level (Spearman rank correlations of 0.32 and 0.26 respectively). For the UK, however, Mitchell, Norman, and Mullin (2015) point to relatively strong disadvantages of deprived areas, with most deprived areas exceeding the least deprived areas by $40 \%$ in $\mathrm{NO}_{2}$ and by $11-14 \%$ in particulate matter $\left(\mathrm{PM}_{10}\right)$. Though the results somewhat point to a lower inequality in general pollution as compared to industrial disamenities in central Europe, it is hard to derive at robust conclusions given that previous studies differ in multiple dimensions. Furthermore, we are not aware of a nationwide empirical study in Germany relying on pollution estimates based on diffusion models of air pollutants.

In this study we thus advance on previous findings in Germany in two ways. First, we investigate if conclusions depend on the measure of pollution. As outlined above, studies based on point sources of industrial emissions in Germany and Austria both find a relatively strong disadvantage of immigrant minorities in terms of pollution levels and the likelihood of living close to environmental disamenities (Glatter-Götz et al., 2019; Rüttenauer, 2018b, 2019a). In contrast, the Swiss study by Diekmann and Meyer (2010) concludes that minorities face only moderate disadvantages based on pollution estimates of diffusion models, and also the local study by Flacke et al. (2016) only identifies moderate associations with socioeconomic position. However, it is needless to say that these differences may stem from multiple sources: a) different types of pollution measures, b) different levels of aggregation (spatially aggregated vs individual level data), or c) existing differences between the countries. In this study, we thus compare the disadvantage of areas with a high share of minorities across different measures of air pollution. Therefore, we use 1) the emissions from (and the distance to) point sources of industrial facilities, and 2) pollution estimates of diffusion models including a wide range of stationary and mobile sources of emission as well as meteorological and topographical conditions. Doing so, we are able to test one possible explanation for the differences in previous findings.

Second, we scrutinise the spatial pattern of environmental inequality in Germany. Previous research in Germany (Rüttenauer, 2018b) has found that the disadvantage of areas with a high share of minorities is approximately twice as strong in urban municipalities than it is within rural municipalities. Furthermore, the pollution disadvantage seems more pronounced in areas where a high share of minorities clusters within cities, which points towards an additional penalty in urban ethnic enclaves and the importance of the urban-suburban divide for environmental inequality (Rüttenauer, 2019a). However, the same study has also shown that conclusions vary quite strongly across geographical regions: while foreigners experience a heavy disadvantage in some cities, other cities exhibit a null-correlation or even negative associations between the share of foreigners and industrial pollution (for similar results in other countries see also Downey, 2007; Glatter-Götz et al., 2019; Padilla et al., 2014). Two important conclusions follow from these findings: 1) the spatial scale (i.e. nationwide, regional, or 
within-municipality) of analysis seems to play a role for the extent of environmental inequality, and 2) conclusions on the presence and extent of environmental inequality might vary across the geographical region under consideration.

To test these assumptions, we employ an explorative modelling technique and analyse the geographical dimensions of environmental inequality with various geographically weighted regressions (GWR). This modelling technique offers two decisive advantages above previous analyses based on the comparison of overall pooled and municipalityfixed effects models. First, we can vary the spatial scale of the study area around any given location, thereby obtaining results which are independent of arbitrary administrative boundaries (e.g. municipality boundaries). This seems especially important if we assume that some barriers restrict the access of minorities to cleaner suburban areas or agglomerations, as these are likely to form a distinct municipality according to administrative boundaries. Second, geographically weighted regressions provide us with an estimate of the minority - pollution disadvantage across space. Thus, for each possible location in Germany and its geographical surrounding of a given size, we can assess the pollution disadvantage associated with the share of foreigners.

\section{Data and Method}

\subsection{Data}

In this study, we combine three different data sources: 1) the German census 2011 (Statistische Ämter des Bundes und der Länder, 2015), 2) data on high-polluting industrial facilities from the European Pollutant Release and Transfer Register (E-PRTR; European Commission, 2006), and 3) pollution estimates of the REMCALGRID diffusion models calculated by the German Environmental Protection Agency (EPA; Schneider, Pelzer, Toengas-Schuller, Nacken, \& Niederau, 2016). The German census is available at the level of a $1 \times 1 \mathrm{~km}$ grid across Germany, and provides demographic information for 93,777 occupied grid cells, containing 778 inhabitants on average. The E-PRTR contains geo-coded information about all industrial facilities exceeding a pollutant-specific threshold (facilities below the threshold are missing). For 2011 this includes 4,974 facilities, of which 1,480 report emissions to air. The EPA pollution model comprises emissions from industrial activities (E-PRTR), household combustion, traffic, and agriculture. The emissions are interpolated across Germany based on emission's point locations, meteorological data, and land use data to derive a geographically distributed estimate of the pollution, which are available at the level of a $2 \times 2 \mathrm{~km}$ grid across Germany.

Note that the first two data sources have been used in Rüttenauer (2018b). However, we advance on this earlier study by adding pollution estimates of diffuse air pollution. Though E-PRTR data are also included in these diffusion models, the EPA data additionally includes emissions from private households and mobile pollution sources like 
traffic. This offers the possibility to assess whether earlier findings based on industrial point sources of emissions still hold when using a broader range of emission sources. To merge the E-PRTR data with the census grids, we apply a buffer method (e.g. Banzhaf \& Walsh, 2008; Mohai \& Saha, 2007) by constructing a $2 \mathrm{~km}$ circle around each industrial facility and allocate the toxicity-weighted emissions proportionate to the intersection between census cell and facility buffer (for more information see Rüttenauer, 2018b). Similarly, we intersect the $1 \times 1 \mathrm{~km}$ census grid and the $2 \times 2 \mathrm{~km}$ EPA pollution grid, and assign each census cell the weighted average across all intersecting pollution cells. In sum, this leaves us with a final dataset of 93,777 observations including information on population, industrial facilities, and estimates of pollution.

\subsection{Variables}

In this study, we rely on a range of different pollution estimates. Following Rüttenauer (2018b), we use the E-PRTR data to calculate the logarithmic toxicity-weighted level of industrial air pollution and the proximity to the nearest industrial facility. From the EPA diffusion model, we get the average estimated amount of nitrogen dioxide $\left(\mathrm{NO}_{2}\right)$, ozone $\left(\mathrm{O}_{3}\right)$, coarse particulate matter $\left(\mathrm{PM}_{10}\right)$, fine particulate matter $\left(\mathrm{PM}_{2.5}\right)$, and sulphur dioxide $\left(\mathrm{SO}_{2}\right)$, which are measured in $\mu \mathrm{g} / \mathrm{m}^{3}$. Figure 1 exemplarily shows the spatial distribution of $\mathrm{NO}_{2}$ and $\mathrm{PM}_{10}$ across Germany. Both pollutants exhibit largescale spatial patterns across the country, with $\mathrm{NO}_{2}$ reaching high concentrations in the mid-west of Germany, and $\mathrm{PM}_{10}$ exhibiting high levels in East Germany and the RheinRuhr area. Based on these pollution estimates, we additionally calculated a pollution index as the average across $\mathrm{NO}_{2}, \mathrm{PM}_{2.5}$, and $\mathrm{SO}_{2}$. In this index we exclude $\mathrm{PM}_{10}$ because of its multicollinearity with $\mathrm{PM}_{2.5}$, and we omit ozone because of its natural negative correlation with the remaining pollutants (Diekmann \& Meyer, 2010). We first standardised the single pollutants and subsequently calculated the mean, thereby assigning an equal weight to each pollutant.

The main demographic variables are derived from the 2011 census data. As the main indicator of minority residents we rely on the percentage of foreigners in each census cell, which are defined as the percentage without German nationality. Note that most empirical studies in the US are centred around racial minority groups. In Germany, however, recent immigrants and their descendants are the main focus of ethnic dissimilarities, and this group experiences comparable disadvantages in other dimensions as racial minorities in the US (e.g. Auspurg et al., 2019). Though we acknowledge that there are likely differences between distinct immigrant or foreign groups (see also Best \& Rüttenauer, 2018), the best available indicator at this spatial level is given by nationality / foreign status. As control variables, we further include the total number of inhabitants, the percentage at age 65 or older, the proportion of vacant housing, and the living space per inhabitant (for the theoretical motivation see Rüttenauer, 2018b). 

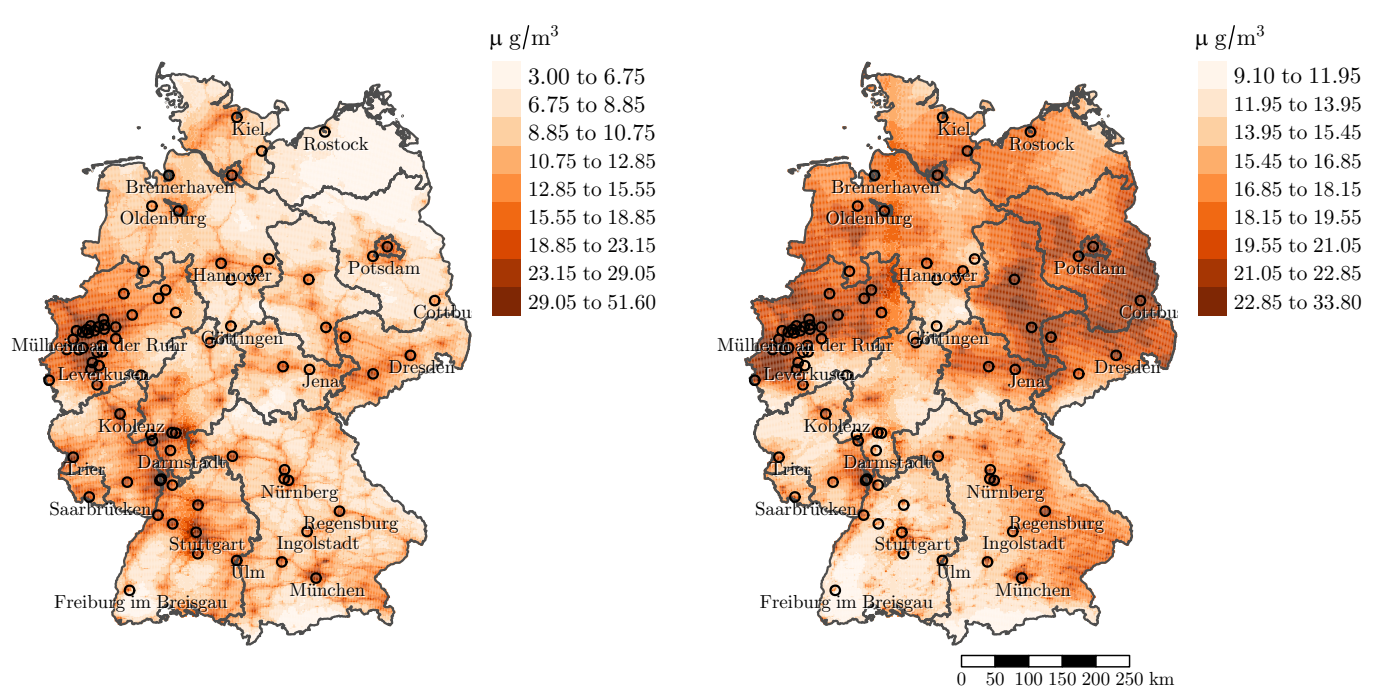

Figure 1. Spatial distribution of $\mathrm{NO}_{2}$ and $\mathrm{PM}_{10}$ estimates across Germany, based on EPA diffusion models.

\subsection{Analytical strategy}

In a first step, we will employ German-wide pooled and municipality-fixed effects spatial lag of X (SLX) models. The first set of pooled models assess if the share of minorities correlates with the level of pollution across Germany in total. However, correlations might stem from large-scale spatial patterns, like minorities being overrepresented in West Germany. The second set of municipality-fixed effects models, in contrast, rules out between-municipality differences and measures the correlation within municipalities only (thus corresponding to local disadvantages). Further, we employ SLX models (Halleck Vega \& Elhorst, 2015; Rüttenauer, 2019b) to account for spatial autocorrelation in the data and to identify clustering effects. Accordingly, Rüttenauer (2018b) has shown that industrial emissions tend to be high in areas where minorities spatially cluster. Formally, the SLX model is defined as

$$
\boldsymbol{y}=\boldsymbol{X} \boldsymbol{\beta}+\boldsymbol{W} \boldsymbol{X} \boldsymbol{\theta}+\boldsymbol{\varepsilon},
$$

where $\boldsymbol{y}$ is a $N \times 1$ vector of the dependent variable, $\boldsymbol{X}$ a $N \times K$ matrix of $K$ covariates, and $\boldsymbol{\varepsilon}$ a $N \times 1$ vector of residuals (for $i=1, \ldots, N$ units). $\boldsymbol{\beta}$ and $\boldsymbol{\theta}$ are $K \times 1$ parameter vectors. $\boldsymbol{W}$ is a spatial weights matrix, which is constructed as a row-normalised contiguity ('Queens') weights matrix, where each element $w_{i j}=1 / n_{i}$ for all $n_{i}$ units sharing a common border, and 0 otherwise. It follows that each row of $\boldsymbol{W} \boldsymbol{X}$ contains the average values of $\boldsymbol{X}$ from the neighbouring units. A positive coefficient of the spatially lagged share of foreigners thus means that pollution is higher where grid cells with a high share of minorities spatially cluster. To estimate these SLX models we use the $R$ package spatialreg (v.1.1-6, Bivand \& Piras, 2015). 
In a second step, we employ geographically weighted regression models (GWR; Brunsdon, Fotheringham, \& Charlton, 1996; Gollini, Lu, Charlton, Brunsdon, \& Harris, 2015). GWR is a explorative tool for spatial data analysis in which we estimate Equation (1) at different geographical points. For $L$ given locations across Germany, we thus receive $L$ different coefficients of the form

$$
\begin{aligned}
& \hat{\boldsymbol{\beta}}_{l}=\left(\boldsymbol{X}^{\boldsymbol{\top}} \boldsymbol{M}_{l} \boldsymbol{X}\right)^{-1} \boldsymbol{X}^{\top} \boldsymbol{M}_{l} \boldsymbol{Y}, \\
& \hat{\boldsymbol{\theta}}_{l}=\left[(\boldsymbol{W} \boldsymbol{X})^{\top} \boldsymbol{M}_{l} \boldsymbol{W} \boldsymbol{X}\right]^{-1}(\boldsymbol{W} \boldsymbol{X})^{\top} \boldsymbol{M}_{l} \boldsymbol{Y},
\end{aligned}
$$

for each location $l=\{1, \ldots, L\}$. The $N \times N$ matrix $\boldsymbol{M}_{l}$ defines the weights at each local point $l$, assigning higher weights to closer units. For these local weights, we use a boxcar kernel density function with a predetermined bandwidth $b$ around each point $l$ (see e.g. Gollini et al., 2015), thereby assigning a weight of zero to all observations outside the bandwidth $b$ and a weight of one to all observations within the bandwidth $b$. Intuitively, this means that we estimate the regression model of Equation (1) for selected geographical subsamples within Germany, thus changing the observations contributing to the model. For instance, GWR with a bandwidth of $40 \mathrm{~km}$ tells us if the share of foreigners in the focal $\left(\beta_{l}\right)$ and adjacent grid cells $\left(\theta_{l}\right)$ correlates with the pollution based on all grid cells within an area of $40 \mathrm{~km}$ radius around the chosen mid-point. No matter of the geographical bandwidth, the spatially lagged term $\boldsymbol{W} \boldsymbol{X}$ is always based on the adjacent units ('Queens' neighbours) of each grid cell.

To analyse how the extent of environmental inequality changes with the geographical scale of the analysis, we estimate the GWR for a range of different bandwidths, going from $9 \mathrm{~km}$ to $600 \mathrm{~km}$ around each location. While the area of $9 \mathrm{~km}$ radius approximately equals the size of medium to large German municipalities like Frankfurt am Main, a $600 \mathrm{~km}$ radius measures environmental inequality at a very large spatial scale, thus approaching a global overall model as in (1). Note that we naturally expect the GWR with a bandwidth of $600 \mathrm{~km}$ to estimate coefficients for each location which are similar to the results obtained from the pooled model of Equation (1). To simplify the computational effort as well as the visualisation of the resulting $L$ coefficients, we here use a $100 \times 150$ cells grid over Germany to determine our regression locations $l$. Further, we reduce these grid-points to locations with at least 40 census cells and 1,000 inhabitants within a radius of $9 \mathrm{~km}$. There is a trade-off between choosing a small starting radius and restricting the sample to areas which still exhibit enough data points and relevant variance within this radius (to avoid singularities). However, additional analyses have shown that starting with a smaller radius does not provide additional insights. This leaves us with a total of 7,285 regression locations at which we estimate Equation (1) based on a subsample within the bandwidth. We use the $R$ packages $G$ Wmodel (v.2.1-4, Gollini et al., 2015) for GWR regressions and tmap for visualisation (v.3.1, Tennekes, 2018). 


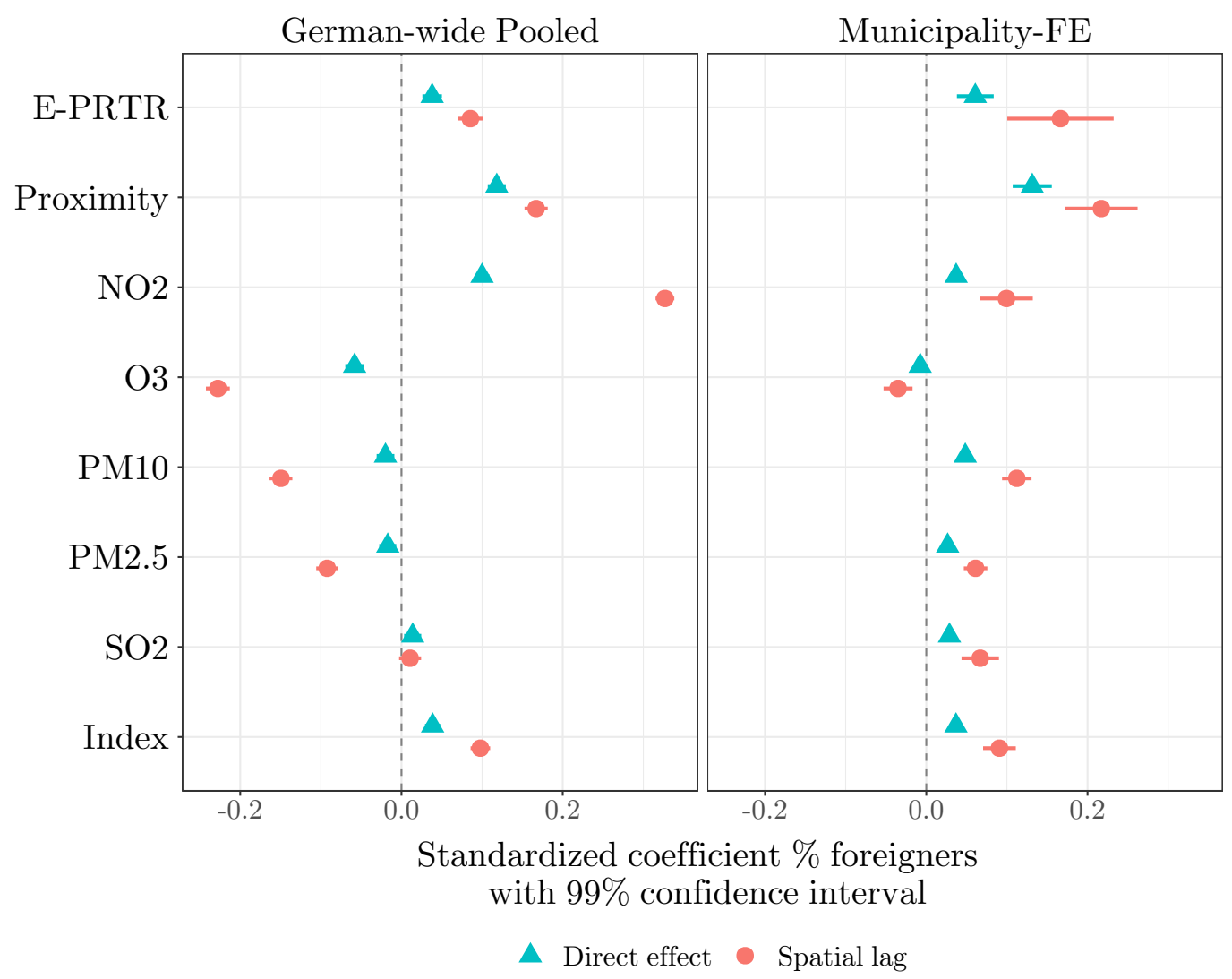

Figure 2. Standardized effect of percentage foreigners and spatially lagged percentage foreigners. Included controls: population, \% 65 and older, \% vacant housing, average living space per inhabitant (all also included as spatial lag), and city dummy in case of pooled models. $N=93,777$ census cells. E-PRTR: toxicity weighted air pollution of industrial facilities; Proximity: proximity to nearest E-PRTR facility. Index: mean of NO2, PM2.5, SO2.

\section{Results}

We first test if conclusions regarding environmental inequality depend on the measure of environmental pollution, or put differently: are minorities disproportionately exposed to air pollution across different measures of pollution? Figure 2 plots the coefficients of the share of foreigners across various measures of pollution as outcome variable (the full results are shown in Appendix A). All models include the above mentioned controls, and we report the direct effect of the focal unit and the indirect effect of neighbouring units, which gives an estimate of spatial clustering effects.

The first two lines of Figure 2 correspond to what we already know from Rüttenauer (2018b): in a German wide comparison as well as within municipalities, a higher share of foreigners is positively correlated with the amount of toxic emissions and the proximity to industrial facilities. Direct coefficients of 0.04 and 0.12 (0.06 and 0.13 within municipalities) standard deviations point to a small to medium disadvantage. However, the indirect clustering effects of 0.08 and 0.17 in the pooled German-wide models, and 0.17 and 0.22 within municipalities point to a relatively strong disadvantage of broader areas 
in which foreigners spatially cluster, especially within municipalities. As a comparison, metropolitan areas on average have a 0.25 standard deviations higher level of industrial pollution and 0.38 standard deviations higher proximity than municipalities below 100,000 inhabitants. The effect of a one standard deviation (or 5.44\%-points) higher share of foreigners - in the focal and the surrounding units - thus seems substantial in comparison. Especially within municipalities, industrial pollution and the proximity to environmental disamenities is disproportionately higher in minority areas.

Turning to the EPA pollution estimates - which additionally account for other nonindustrial sources of emissions - we however observe a relatively heterogeneous picture in the German-wide pooled models (left panel). For $\mathrm{NO}_{2}$, conclusions align with the E-PRTR measures. Foreigners are exposed to higher $\mathrm{NO}_{2}$ levels, and the strength of the spatial lag even exceeds findings of industrial emissions. The direction of the effect is similar for $\mathrm{SO}_{2}$ and the combined index, but the strength of the disadvantage is much lower. For $\mathrm{O}_{3}, \mathrm{PM}_{10}$, and $\mathrm{PM}_{2.5}$, conclusions in contrast differ drastically: those pollutants are lower in areas with a higher share of minorities. For $\mathrm{O}_{3}$ we would expect this finding given its negative correlation with other pollutants and its high value in rural and suburban regions. Though results for particulate matter seem surprising at first inspection, this negative correlation is a result of the high levels of particulate matter in East Germany (see Figure 1), where foreigners are historically under-represented. Because of these large-scale patterns of particulate matter, foreigners live in regions with lower than average particulate matter.

Accordingly, the negative correlation with particulate matter vanishes once we take these large scale differences into account by estimating municipality-fixed effects models (right panel). Except of ozone, all measures point to a positive correlation between the share of foreigners and the amount of air pollution. Within municipalities, minorities tend to live in neighbourhoods, which have a higher level of air pollution across all measures except ozone. In terms of substantive magnitude, this disadvantage is lower than the disadvantage estimated by relying on information from industrial facilities only. For the combined index of pollution, for instance, the within-city effect in standard deviations corresponds to 0.04 for the focal and 0.09 for the spatial lag. Though the results do not differ heavily from the coefficients of E-PRTR pollution in terms of standard deviations (0.06 and 0.17), there seems to be a pronounced difference in substantive significance. Net of common controls, the pollution index level in urban areas exceeds the average non-urban level by 1.01 standard deviations ( 0.25 for E-PRTR pollution). The total within-city disadvantage associated with a 5.44\%-points higher share of foreign minorities (direct + spatial lag) thus equals $12 \%$ of the disadvantage of living in an urban area. For hazardous E-PRTR emissions, in contrast, we find a minority effect which corresponds to $93 \%$ of the urban pollution disadvantage. Even though the conclusion of a disadvantage of foreign minorities remains unchanged across all measures (except ozone), the extent of environmental inequality in substantive terms seems sensitive to the measure of environmental pollution. 


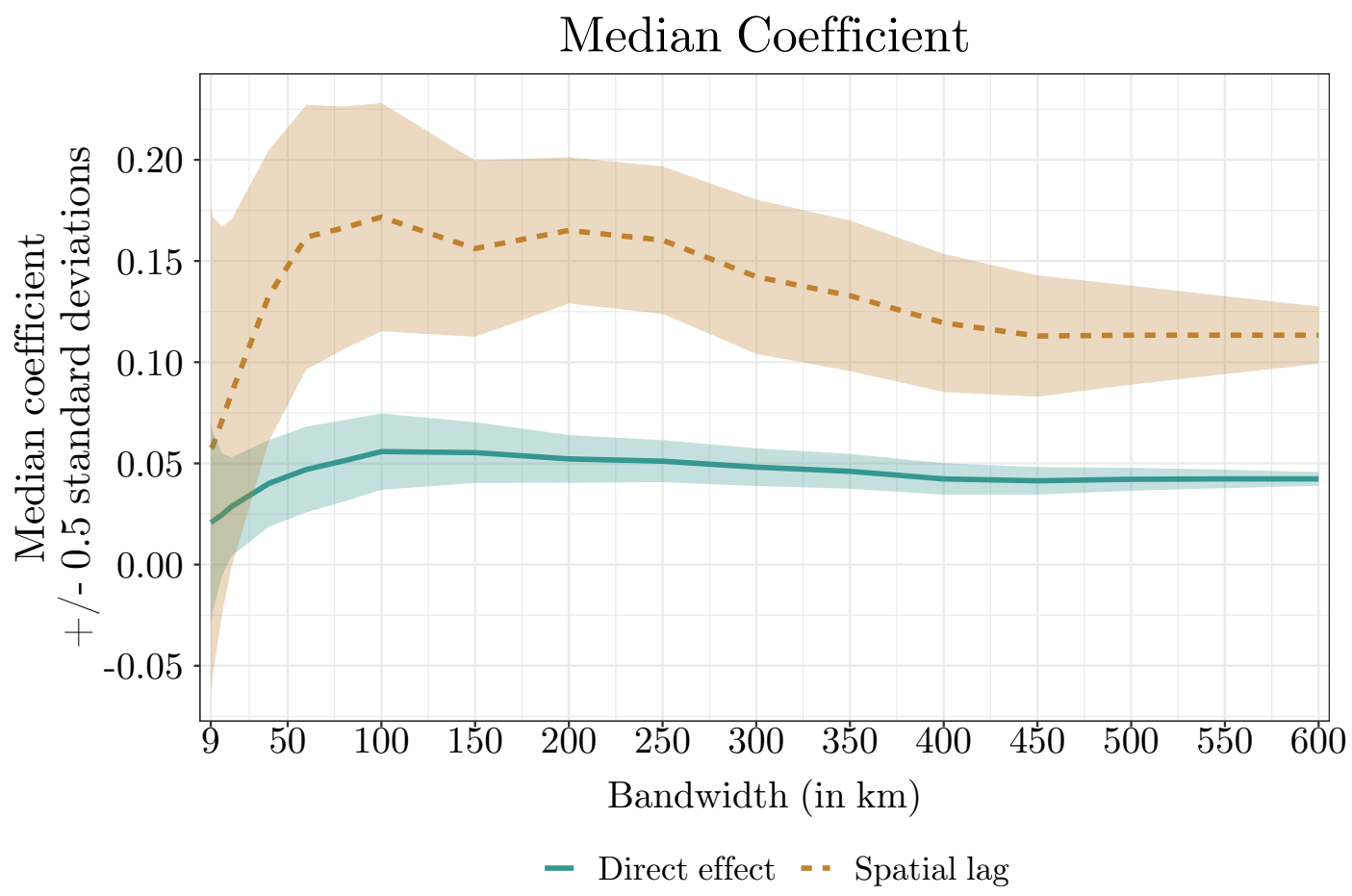

Figure 3. Median coefficient of share of foreigners and spatially lagged share of foreigners from GWR models across a range of kernel bandwidths. The shaded areas show the standard deviation of the coefficients across 7,285 location points in each bandwidth.

As we have argued earlier, another dimension which might influence the conclusions of empirical environmental inequality studies is the geographic location and scale of the analysis. To test this hypothesis, we estimate a series of GWR models for a wide range of spatial bandwidths. To simplify the presentation of results, we focus on the pollution index as dependent variable, averaging across $\mathrm{NO}_{2}, \mathrm{PM}_{2.5}$, and $\mathrm{SO}_{2}$. Results are depicted in two different ways.

First, Figure 3 shows how the median conditional correlation between the percentage of foreigners and the pollution index changes over the range of geographical bandwidths, thus indicating how environmental inequality varies with the geographical scale. The shaded area furthermore depicts the standard deviation of the coefficients across the 7,285 regressions in each bandwidth. All models include the above mentioned controls except of the city dummy, which we need to omit because of potential singularities. The strength of the direct coefficient first increases from 0.03 at $9 \mathrm{~km}$ up to a bandwidth of $100 \mathrm{~km}$, reaching a value of 0.06 , and subsequently decreases again. Considering the standard deviation within each bandwidth, local levels below $20 \mathrm{~km}$ exhibit a high amount of heterogeneity in the disadvantage of foreigners. With broader bandwidths, the median coefficient of the GWR obviously approaches the coefficient of 0.04 from the overall pooled model (Figure 2). By trend, the spatially lagged or clustering effect follows a similar path: starting at a value of 0.06 at $9 \mathrm{~km}$, the coefficient reaches its 
maximum of 0.17 at a bandwidth of $100 \mathrm{~km}$, before it approaches towards the overall effect of 0.10 standard deviations.

In sum, this provides us with two important insights: 1) there is strong variation in the disadvantage of foreigners at the more local level $(\leq 20 \mathrm{~km})$ across Germany, and 2) the average pollution-disadvantage in Germany reaches its maximum when considering medium-scaled areas with a bandwidth of around $100 \mathrm{~km}$. To give a reference point, the area of Berlin $\left(891 \mathrm{~km}^{2}\right)$ approximately fits into a circle with a bandwidth of $17 \mathrm{~km}$. The results thus indicate that the relative disadvantage of minorities is strongest at a spatial scale far beyond the level of municipalities or cities. Obviously, the result on this scale may be driven by the differences in pollution between metropolitan and rural / suburban areas, with minorities being over-represented in in polluted inner-city regions and under-represented in rural and suburban regions.

Second, we look at how the association varies with location. Figure 4 graphically shows the extent of environmental inequality across the 7,285 regression mid-points for two bandwidths: $40 \mathrm{~km}$ in the top panel and $100 \mathrm{~km}$ in the bottom panel. At the local level of $40 \mathrm{~km}$, coefficients range from negative values of -0.20 to positive values of 0.53 (-0.46 to 1.13 for the spatial clustering effect). This highlights that there are regions in which minorities actually have a pollution advantage, but other areas with a strong disadvantage for minorities (which is in line with previous results, e.g. Padilla et al., 2014; Rüttenauer, 2019a). However, at this spatial scale, it is hard to detect a general spatial pattern. Across all regions, we observe some areas with a weaker and other areas with a stronger correlation. Nevertheless, the top panel of Figure 4 provides some indication for higher levels of environmental inequality around larger cities (as indicated by the circles). Especially high spatial clustering effects (right side) can be found around metropolitan areas, for instance in the Rhine-Ruhr metropolitan region or around Munich and Nuremberg. This provides further support for the hypothesis that urban-suburban differences in pollution and the share of foreigners add to the unequal distribution of pollution.

The bottom panel of Figure 4 depicts large scale differences in environmental inequality across Germany. Though this is the scale on which we observe the strongest average disadvantage of minorities (Figure 3), there are large differences across Germany. In some regions - mainly North Rhine-Westphalia, Saxony, Saxony-Anhalt, and Thuringia - GWR estimates correlations which are either slightly negative or close to zero. Foreign minorities are not exposed to a pollution disadvantage in those regions compared to observations within a reach of $100 \mathrm{~km}$, though they are on a smaller scale inside those regions (upper panel). In contrast, minorities experience a relatively strong disadvantage in central and northern parts of Germany on this large spatial scale. In those regions, areas with a higher share of minorities also exhibit a higher than average level of air pollution. These large scale patterns of environmental inequality are unlikely to be driven by general population patterns, as North Rhine-Westphalia shows low levels of environmental inequality despite a high population density. 
40km: Direct effect \% Foreigners

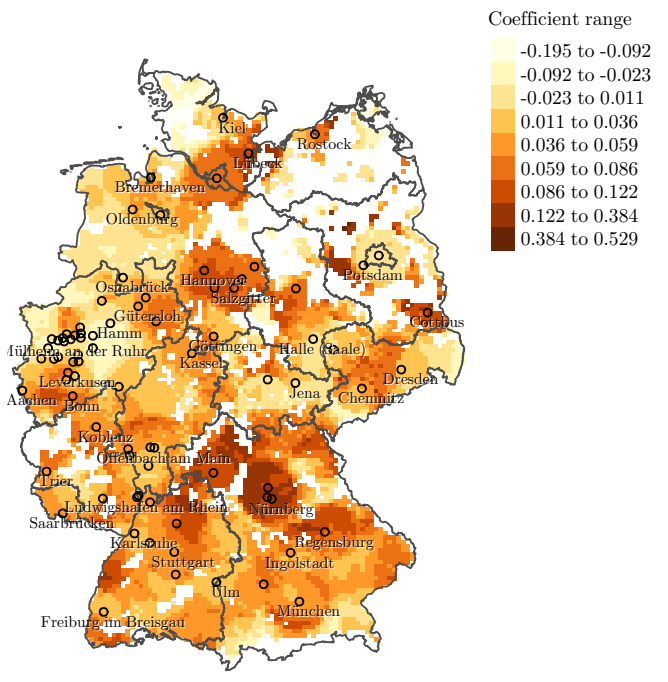

100km: Direct effect \% Foreigners

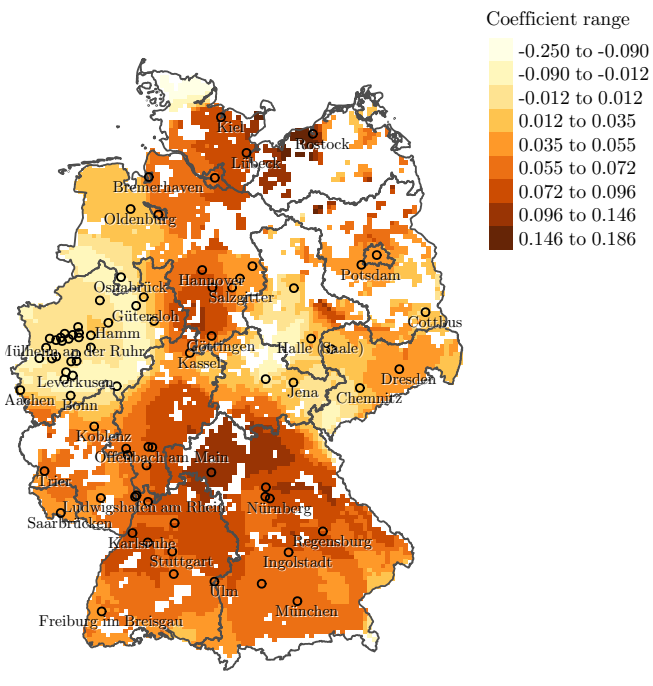

40km: Spatial lag \% Foreigners

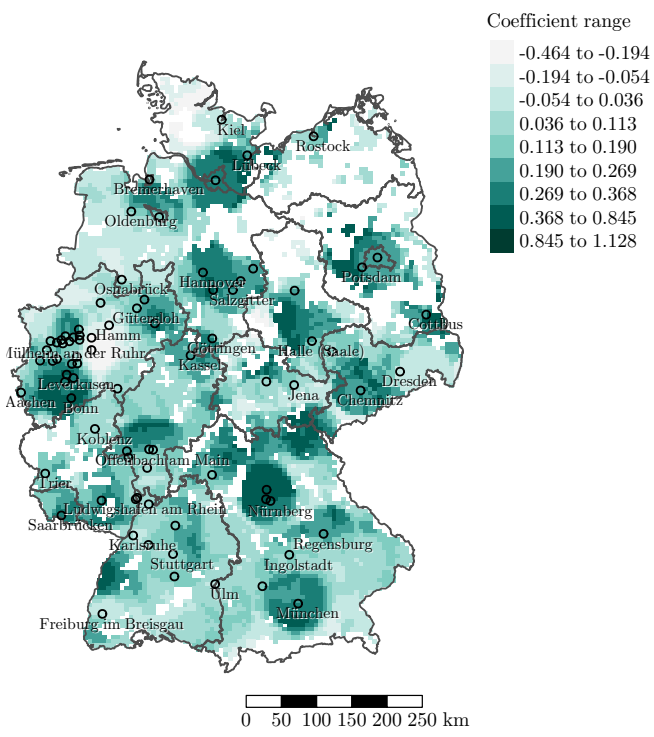

100km: Spatial lag \% Foreigners

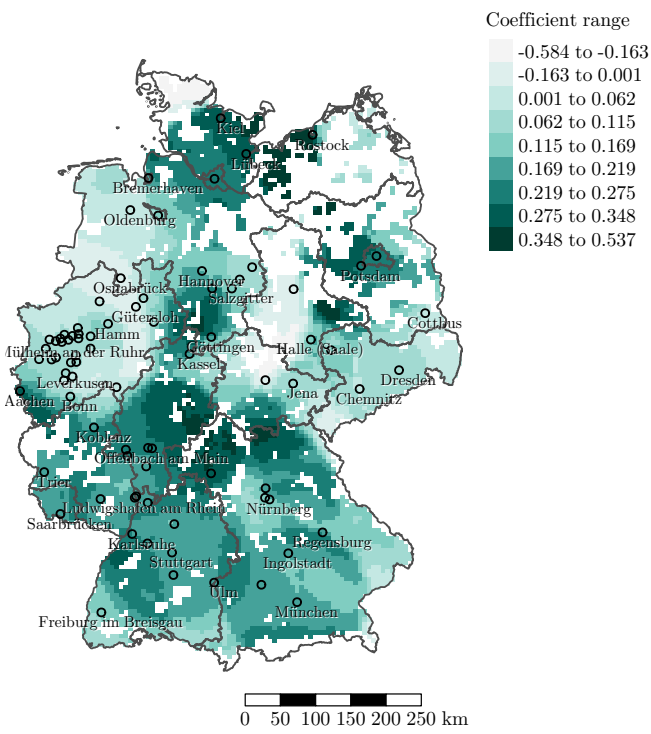

Figure 4. Direct and spatially lagged coefficient of percentage foreigners based on geographically weighted regressions for different bandwidths based. Dependent variable is the pollution index of NO2, PM2.5, and SO2. Controls as in Figure 2.

This second set of results offers a range of implications. First, the extent of environmental inequality depends on the spatial scale of the analysis. In contrast to previous assumptions (Rüttenauer, 2018b), the strongest average disadvantage does not occur on an within-municipality level, but rather when analysing larger geographic areas, potentially including urban and rural areas. Second, some areas show low levels of inequality on a large scale, but still exhibit environmental inequality on the local scale. By trend, environmental inequality on the local level seems larger around urban areas, 
which again speaks for a causal channel operating through differences in residency between urban core-areas and suburban regions. Nevertheless, it is important to keep in mind that these findings are descriptive, and hypotheses about the generating process remain speculative.

\section{Discussion}

Air pollution is known to have strong adverse health effects and is also likely to influence other dimensions of social life. Thus, it comes with no surprise that social sciences in Europe have gained increasing interest in the topic of environmental inequality. Though previous studies in Germany and other European countries have shown that minorities are on average exposed to higher levels of pollution, there is strong variation in the extent of this disadvantage. In this study, we test two possible explanations for diverging results in previous studies: 1) the use of different pollution measures, and 2) the spatial scale and location of the analysis within Germany.

Our results show that conclusions of nationwide analyses depend heavily on largescale pollution patterns. While foreign minorities are over-represented in areas with higher levels of industrial pollution as well as $\mathrm{NO}_{2}$ and $\mathrm{SO}_{2}$, they tend to be less affected by particulate matter and ozone. Within municipalities, in contrast, foreign minorities tend to live in areas with a higher amount of air pollution across all measures employed in this study, with the only exception of ozone. The finding of a pollution disadvantage of minorities within municipalities is thus strikingly consistent. The substantive strength of this disadvantage varies however across the different measures. When using the difference between urban and non-urban areas as a reference, the disadvantage seems substantial in terms of industrial emissions and the proximity to industrial disamenities, but it is rather week regarding pollution estimates of various sources of emissions. Though this finding can explain differences in previous studies, it is hard to speculate on the reason for the diverging findings based on our data. It might be that the relative coarseness of the pollution estimates $(2 \times 2 \mathrm{~km})$ masks important differences within municipalities, as we artificially reduce the spatial variance. Nonetheless, minorities might also experience a stronger disadvantage in industrial air pollution, while emissions from households and transportation are more equally distributed across the society.

Further, we show that conclusions regarding the strength of environmental inequality in Germany depend on the spatial scale of the study. While the average disadvantage is rather small at the local level, it increases to its maximum at a large regional level of around 100km. This large scale disadvantage is more pronounced in central Germany, and less so in Western and Eastern parts. However, large regions with a low level of coarse environmental inequality can still exhibit some hotspot areas of environmental inequality at the lower level. At the local geographical level, we find that the unequal distribution of air pollution is especially high around metropolitan areas. Even though 
these results are only explorative, the spatial patterns support the idea that minorities experience a pollution penalty because of the residency in inner-city areas. As it has been argued earlier (e.g. Alba et al., 1999; Logan et al., 2002; Winke, 2018), inner-city districts are likely to provide beneficial opportunity structures for immigrant-minorities. At the same time, barriers on the housing market restrict the access of minorities to cleaner suburban or rural areas. Regardless of the reason, the tendency of living in urban core areas seems a plausible contributor to the disproportionate exposure of minorities to environmental pollution.

Though we find that conclusions are to some extent sensitive to pollution measures and spatial scale, we can only speculate on the reasons of this heterogeneity. For instance, actual pollution levels are hard to observe, while industrial disamenities are easily visible. Thus, selective migration processes may be more reactive to industrial facilities than to average levels of air pollution. To test these theoretical assumptions, further research needs to combine longitudinal migration trajectories to pollution estimates and the location of environmental disamenities. In addition, individual level survey data and pollution estimates should be used to assess the substantive strength of environmental inequality in Germany. It is important to derive an estimate of how the air pollution gap connects to other dimensions of inequality, like health inequalities or educational achievement gaps. In sum, we are confident that much can be learned from future research connecting the aggregated level of environmental hazards to individuallevel data over time. 


\section{References}

Alba, R. D., Logan, J. R., Stults, B. J., Marzan, G., \& Zhang, W. (1999). Immigrant Groups in the Suburbs: A Reexamination of Suburbanization and Spatial Assimilation. American Sociological Review, 64(3), 446-460.

Anderton, D. L., Anderson, A. B., Oakes, J. M., \& Fraser, M. R. (1994). Environmental Equity: The Demographics of Dumping. Demography, 31(2), 229-248.

Auspurg, K., Schneck, A., \& Hinz, T. (2019). Closed Doors Everywhere? A Meta-Analysis of Field Experiments on Ethnic Discrimination in Rental Housing Markets. Journal of Ethnic and Migration Studies, 45(1), 95-114.

Banzhaf, H. S., Ma, L., \& Timmins, C. (2019a). Environmental Justice: Establishing Causal Relationships. Annual Review of Resource Economics, 11(1), 377-398.

Banzhaf, H. S., Ma, L., \& Timmins, C. (2019b). Environmental Justice: The Economics of Race, Place, and Pollution. Journal of Economic Perspectives, 33(1), 185-208.

Banzhaf, H. S., \& McCormick, E. (2012). Moving beyond Cleanup: Identifying the Crucibles of Environmental Gentrification. In H. S. Banzhaf (Ed.), The Political Economy of Environmental Justice (pp. 23-51). Palo Alto: Stanford Univ. Press.

Banzhaf, H. S., Sidon, J., \& Walsh, R. P. (2012). Environmental Gentrification and Discrimination. In H. S. Banzhaf (Ed.), The Political Economy of Environmental Justice (pp. 75-111). Palo Alto: Stanford Univ. Press.

Banzhaf, H. S., \& Walsh, R. P. (2008). Do People Vote with Their Feet? An Empirical Test of Tiebout's Mechanism. American Economic Review, 98(3), 843-863.

Bayer, P., Keohane, N., \& Timmins, C. (2009). Migration and Hedonic Valuation: The Case of Air Quality. Journal of Environmental Economics and Management, 58(1), 1-14.

Been, V. (1994). Locally Undesirable Land Uses in Minority Neighborhoods: Disproportionate Siting or Market Dynamics? The Yale Law Journal, 103(6), 1383.

Been, V., \& Gupta, F. (1997). Coming to the Nuisance or Going to the Barrios - A Longitudinal Analysis of Environmental Justice Claims. Ecology Law Quarterly, 24(1), 1-56.

Best, H., \& Rüttenauer, T. (2018). How Selective Migration Shapes Environmental Inequality in Germany: Evidence from Micro-Level Panel Data. European Sociological Review, 34 (1), $52-63$.

Bivand, R., \& Piras, G. (2015). Comparing Implementations of Estimation Methods for Spatial Econometrics. Journal of Statistical Software, 63(18), 1-36.

Brunsdon, C., Fotheringham, A. S., \& Charlton, M. E. (1996). Geographically Weighted Regression: A Method for Exploring Spatial Nonstationarity. Geographical Analysis, 28 (4), $281-298$.

Bryant, B., \& Mohai, P. (1992). Race and the Incidence of Envrionmental Hazards: A Time for Discourse. Boulder: Westview.

Bullard, R. D. (1990). Dumping in Dixie: Race, Class, and Environmental Quality. Boulder: Westview.

Colmer, J., Hardman, I., Shimshack, J., \& Voorheis, J. (2020). Disparities in PM2.5 air pollution in the United States. Science, 369(6503), 575-578.

Crowder, K., \& Downey, L. (2010). Inter-Neighborhood Migration, Race, and Environmental Hazards: Modeling Micro-Level Processes of Environmental Inequality. American Journal of Sociology, 115(4), 1110-1149.

Crowder, K., South, S. J., \& Chavez, E. (2006). Wealth, Race, and Inter-Neighborhood Migration. American Sociological Review, 71(1), 72-94.

Diekmann, A., \& Meyer, R. (2010). Demokratischer Smog? Eine empirische Untersuchung zum Zusammenhang zwischen Sozialschicht und Umweltbelastungen. Kölner Zeitschrift für Soziologie und Sozialpsychologie, 62(3), 437-457.

Downey, L. (2005). The Unintended Significance of Race: Environmental Racial Inequality in Detroit. Social Forces, 83(3), 971-1007. 
Downey, L. (2007). US Metropolitan-Area Variation in Environmental Inequality Outcomes. Urban Studies, $44(5-6), 953-977$.

European Commission. (2006). Guidance Document for the Implementation of the European PRTR. Retrieved 02.05.2016, from http://prtr.ec.europa.eu/docs/en_prtr.pdf

European Environment Agency. (2019). Air Quality in Europe - 2019 Report. Luxembourg. Retrieved 21.10.2019, from https://www. eea.europa.eu/publications/air-quality-in -europe-2019

Farber, S. (1998). Undesirable Facilities and Property Values: A Summary of Empirical Studies. Ecological Economics, 24(1), 1-14.

Flacke, J., Schüle, S. A., Köckler, H., \& Bolte, G. (2016). Mapping Environmental Inequalities Relevant for Health for Informing Urban Planning Interventions - A Case Study in the City of Dortmund, Germany. International Journal of Environmental Research and Public Health, 13(7), 711.

Franzen, A., \& Vogl, D. (2013). Acquiescence and the Willingness to Pay for Environmental Protection: A Comparison of the ISSP, WVS, and EVS. Social Science Quarterly, $94(3)$, 637-659.

Glatter-Götz, H., Mohai, P., Haas, W., \& Plutzar, C. (2019). Environmental Inequality in Austria: Do Inhabitants' Socioeconomic Characteristics Differ Depending on Their Proximity to Industrial Polluters? Environmental Research Letters, 14(7), 074007.

Gollini, I., Lu, B., Charlton, M., Brunsdon, C., \& Harris, P. (2015). GWmodel : An R Package for Exploring Spatial Heterogeneity Using Geographically Weighted Models. Journal of Statistical Software, 63(17).

Halleck Vega, S., \& Elhorst, J. P. (2015). The SLX Model. Journal of Regional Science, $55(3)$, $339-363$.

Hamilton, J. T. (1995). Testing for Environmental Racism: Prejudice, Profits, Political Power? Journal of Policy Analysis and Management, 14(1), 107-132.

Jünger, S. (2021). Land use disadvantages in germany: A matter of ethnic income inequalities? Urban Studies, OnlineFirst.

Kabisch, N., \& Haase, D. (2014). Green Justice or Just Green? Provision of Urban Green Spaces in Berlin, Germany. Landscape and Urban Planning, 122, 129-139.

Kohlhuber, M., Mielck, A., Weiland, S. K., \& Bolte, G. (2006). Social Inequality in Perceived Environmental Exposures in Relation to Housing Conditions in Germany. Environmental Research, $101(2), 246-255$.

Krysan, M., Couper, M. P., Farley, R., \& Forman, T. A. (2009). Does Race Matter in Neighborhood Preferences? Results from a Video Experiment. American Journal of Sociology, $115(2), 527-559$.

Landrigan, P. J., Fuller, R., Acosta, N. J. R., Adeyi, O., Arnold, R., Basu, N., ... Zhong, M. (2018). The Lancet Commission on Pollution and Health. The Lancet, 391 (10119), $462-512$.

Liebe, U., Preisendörfer, P., \& Meyerhoff, J. (2010). To Pay or Not to Pay: Competing Theories to Explain Individuals' Willingness to Pay for Public Environmental Goods. Environment and Behavior, 43(1), 106-130.

Logan, J. R., \& Alba, R. D. (1993). Locational Returns to Human Capital: Minority Access to Suburban Community Resources. Demography, 30(2), 243-268.

Logan, J. R., Zhang, W., \& Alba, R. D. (2002). Immigrant Enclaves and Ethnic Communities in New York and Los Angeles. American Sociological Review, 67(2), 299-322.

Martén, L., Hainmueller, J., \& Hangartner, D. (2019). Ethnic Networks Can Foster the Economic Integration of Refugees. Proceedings of the National Academy of Sciences of the United States of America, 116(33), 16280-16285.

Massey, D. S., \& Denton, N. A. (1988). The Dimensions of Residential Segregation. Social Forces, 67(2), 281-315.

Massey, D. S., \& Denton, N. A. (1993). American Apartheid: Segregation and the Making of 
the Underclass. Cambridge, Mass: Harvard Univ. Press.

Mears, M., Brindley, P., Maheswaran, R., \& Jorgensen, A. (2019). Understanding the Socioeconomic Equity of Publicly Accessible Greenspace Distribution: The Example of Sheffield, UK. Geoforum, 103, 126-137.

Meyer, R., \& Liebe, U. (2010). Are the Affluent Prepared to Pay for the Planet? Explaining Willingness to Pay for Public and Quasi-Private Environmental Goods in Switzerland. Population and Environment, 32(1), 42-65.

Mitchell, G., Norman, P., \& Mullin, K. (2015). Who Benefits from Environmental Policy? An Environmental Justice Analysis of Air Quality Change in Britain, 2001-2011. Social Science Quarterly, 10(10), 105009.

Mohai, P., Pellow, D., \& Roberts, J. T. (2009). Environmental Justice. Annual Review of Environment and Resources, 34(1), 405-430.

Mohai, P., \& Saha, R. (2007). Racial Inequality in the Distribution of Hazardous Waste: A National-Level Reassessment. Social Problems, 54(3), 343-370.

Mohai, P., \& Saha, R. (2015). Which Came First, People or Pollution? A Review of Theory and Evidence from Longitudinal Environmental Justice Studies. Environmental Research Letters, 10 (12), 125011.

Ondrich, J., Ross, S., \& Yinger, J. (2003). Now You See It, Now You Don't: Why Do Real Estate Agents Withhold Available Houses from Black Customers? Review of Economics and Statistics, 85(4), 854-873.

Padilla, C. M., Kihal-Talantikite, W., Vieira, V. M., Rossello, P., Le Nir, G., Zmirou-Navier, D., \& Deguen, S. (2014). Air Quality and Social Deprivation in Four French Metropolitan Areas: A Localized Spatio-Temporal Environmental Inequality Analysis. Environmental Research, 134, 315-324.

Pais, J., Crowder, K., \& Downey, L. (2014). Unequal Trajectories: Racial and Class Differences in Residential Exposure to Industrial Hazard. Social Forces, 92(3), 1189-1215.

Pasetto, R., Mattioli, B., \& Marsili, D. (2019). Environmental Justice in Industrially Contaminated Sites. A Review of Scientific Evidence in the WHO European Region. International Journal of Environmental Research and Public Health, 16 (6), 1-20.

Pastor, M., Sadd, J., \& Hipp, J. R. (2001). Which Came First? Toxic Facilities, Minority Move-in, and Environmental Justice. Journal of Urban Affairs, 23(1), 1-21.

Persico, C. (2020). Can Pollution Cause Poverty? The Effects of Pollution on Educational, Health and Economic Outcomes. IZA Discussion Papers(12965).

Raddatz, L., \& Mennis, J. (2013). Environmental Justice in Hamburg, Germany. The Professional Geographer, 65(3), 495-511.

Rüttenauer, T. (2018a). Environmental Inequality in Germany (Doctoral dissertation, Technische Universität Kaiserslautern, Kaiserslautern). Retrieved from https://kluedo.ub.uni -kl.de/frontdoor/index/index/docId/5421

Rüttenauer, T. (2018b). Neighbours Matter: A Nation-Wide Small-Area Assessment of Environmental Inequality in Germany. Social Science Research, 70, 198-211.

Rüttenauer, T. (2019a). Bringing Urban Space Back in: A Multilevel Analysis of Environmental Inequality in Germany. Urban Studies, 56(12), 2549-2567.

Rüttenauer, T. (2019b). Spatial Regression Models: A Systematic Comparison of Different Model Specifications Using Monte Carlo Experiments. Sociological Methods \& Research, OnlineFirst.

Saha, R., \& Mohai, P. (2005). Historical Context and Hazardous Waste Facility Siting: Understanding Temporal Patterns in Michigan. Social Problems, 52(4), 618-648.

Schneider, C., Pelzer, M., Toengas-Schuller, N., Nacken, M., \& Niederau, A. (2016). ArcGIS basierte Lösung zur detaillierten, deutschlandweiten Verteilung (Gridding) nationaler Emissionsjahreswerte auf Basis des Inventars zur Emissionsberichterstattung. Dessau-Roßlau. Retrieved 27.04.2019, from https://www.umweltbundesamt.de/sites/default/files/ medien/1968/publikationen/2016-11-09_griddingtool_greta_langfassung_final .pdf 
Semyonov, M., Grodzeisky, A., \& Glikman, A. (2012). Neighborhood Ethnic Composition and Resident Perceptions of Safety in European Countries. Social Problems, 59(1), 117-135.

Sieg, H., Smith, V. K., Banzhaf, H. S., \& Walsh, R. P. (2004). Estimating the General Equilibrium Benefits of Large Changes in Spatially Delineated Public Goods. International Economic Review, 45(4), 1047-1077.

South, S. J., Huang, Y., Spring, A., \& Crowder, K. (2016). Neighborhood Attainment over the Adult Life Course. American Sociological Review, 81(6), 1276-1304.

Statistische Ämter des Bundes und der Länder. (2015). Zensus 2011: Metoden und Berichte. Wiesbaden. Retrieved 20.03.2017, from https://www.zensus2011.de/SharedDocs/ Downloads/DE/Publikationen/Aufsaetze_Archiv/2015_06_MethodenUndVerfahren .pdf

Tennekes, M. (2018). tmap : Thematic Maps in R. Journal of Statistical Software, 84(6).

Tiebout, C. M. (1956). A Pure Theory of Local Expenditures. The Journal of Political Economy, 64(5), 416-424.

Turner, M. A., \& Ross, S. (2005). How Racial Discrimination Affects the Search for Housing. In De Souza Briggs, Xavier N. (Ed.), The Geography of Opportunity (pp. 81-100). Washington D.C: Brookings Institution Press.

United Church of Christ - Commission for Racial Justice. (1987). Toxic Wastes and Race in the United States: A National Report on the Racial and Socioeconomic Characteristics of Communities with Hazardous Waste Sites. New York: United Church of Christ.

Weigand, M., Wurm, M., Dech, S., \& Taubenböck, H. (2019). Remote Sensing in Environmental Justice Research-A Review. ISPRS International Journal of Geo-Information, 8(1), $1-28$.

Winke, T. (2018). Being Close to Ethnic Peers: The Formation of Ethnic Residential Clustering from a Household Perspective. Journal of Ethnic and Migration Studies, 44(11), 19321953.

Wolverton, A. (2009). Effects of Socio-Economic and Input-Related Factors on Polluting Plants' Location Decisions. The B.E. Journal of Economic Analysis \& Policy, 9(1).

Wolverton, A. (2012). The Role of Demographic and Cost-Related Factors in Determining Where Plants Locate: A Tale of Two Texas Cities. In H. S. Banzhaf (Ed.), The Political Economy of Environmental Justice (pp. 199-222). Palo Alto: Stanford Univ. Press.

Wüstemann, H., Kalisch, D., \& Kolbe, J. (2017). Access to Urban Green Space and Environmental Inequalities in Germany. Landscape and Urban Planning, 164, 124-131.

Yinger, J. (1986). Measuring Racial Discrimination with Fair Housing Audits: Caught in the Act. The American Economic Review, 76(5), 881-893. 


\section{Appendix A. SLX Regression results}

Table A1. Pooled SLX models.

\begin{tabular}{|c|c|c|c|c|c|c|c|c|}
\hline & $\begin{array}{c}\text { E-PRTR } \\
(1)\end{array}$ & $\begin{array}{c}\text { Prox } \\
(2) \\
\end{array}$ & $\begin{array}{l}\text { NO2 } \\
(3)\end{array}$ & $\begin{array}{l}\text { O3 } \\
(4) \\
\end{array}$ & $\begin{array}{c}\text { PM10 } \\
(5)\end{array}$ & $\begin{array}{c}\text { PM2.5 } \\
(6)\end{array}$ & $\begin{array}{c}\mathrm{SO} 2 \\
(7)\end{array}$ & $\begin{array}{c}\text { Index } \\
(8) \\
\end{array}$ \\
\hline$\%$ Foreigners & $\begin{array}{l}0.038^{* * *} \\
(0.005)\end{array}$ & $\begin{array}{l}0.118^{* * *} \\
(0.004)\end{array}$ & $\begin{array}{l}0.100^{* * *} \\
(0.004)\end{array}$ & $\begin{array}{c}-0.058^{* * *} \\
(0.004)\end{array}$ & $\begin{array}{c}-0.020^{* * *} \\
(0.004)\end{array}$ & $\begin{array}{c}-0.017^{* * *} \\
(0.004)\end{array}$ & $\begin{array}{l}0.014^{* * *} \\
(0.004)\end{array}$ & $\begin{array}{l}0.039^{* * *} \\
(0.004)\end{array}$ \\
\hline W \% Foreigners & $\begin{array}{l}0.085^{* * *} \\
(0.006)\end{array}$ & $\begin{array}{l}0.167^{* * *} \\
(0.006)\end{array}$ & $\begin{array}{l}0.327^{* * *} \\
(0.005)\end{array}$ & $\begin{array}{c}-0.228^{* * *} \\
(0.006)\end{array}$ & $\begin{array}{c}-0.149^{* * *} \\
(0.005)\end{array}$ & $\begin{array}{c}-0.092^{* * *} \\
(0.005)\end{array}$ & $\begin{array}{c}0.011^{*} \\
(0.005)\end{array}$ & $\begin{array}{l}0.098^{* * *} \\
(0.005)\end{array}$ \\
\hline Population & $\begin{array}{c}-0.006 \\
(0.005)\end{array}$ & $\begin{array}{c}-0.035^{* * *} \\
(0.005)\end{array}$ & $\begin{array}{l}0.022^{* * *} \\
(0.004)\end{array}$ & $\begin{array}{l}0.024^{* * *} \\
(0.005)\end{array}$ & $\begin{array}{l}0.032^{* * *} \\
(0.004)\end{array}$ & $\begin{array}{l}0.038^{* * *} \\
(0.004)\end{array}$ & $\begin{array}{l}0.042^{* * *} \\
(0.004)\end{array}$ & $\begin{array}{l}0.041^{* * *} \\
(0.004)\end{array}$ \\
\hline W Population & $\begin{array}{c}0.001 \\
(0.007)\end{array}$ & $\begin{array}{l}0.179^{* * *} \\
(0.007)\end{array}$ & $\begin{array}{l}0.245^{* * *} \\
(0.005)\end{array}$ & $\begin{array}{c}-0.036^{* * *} \\
(0.007)\end{array}$ & $\begin{array}{l}0.301^{* * *} \\
(0.006)\end{array}$ & $\begin{array}{l}0.304^{* * *} \\
(0.006)\end{array}$ & $\begin{array}{l}0.218^{* * *} \\
(0.006)\end{array}$ & $\begin{array}{l}0.306^{* * *} \\
(0.006)\end{array}$ \\
\hline$\% 65$ and older & $\begin{array}{c}0.003 \\
(0.003)\end{array}$ & $\begin{array}{l}0.014^{* * *} \\
(0.003)\end{array}$ & $\begin{array}{l}0.010^{* * *} \\
(0.003)\end{array}$ & $\begin{array}{l}0.057^{* * *} \\
(0.003)\end{array}$ & $\begin{array}{l}0.041^{* * *} \\
(0.003)\end{array}$ & $\begin{array}{l}0.045^{* * *} \\
(0.003)\end{array}$ & $\begin{array}{l}0.039^{* * *} \\
(0.003)\end{array}$ & $\begin{array}{l}0.037^{* * *} \\
(0.003)\end{array}$ \\
\hline W \% 65 and older & $\begin{array}{c}0.006 \\
(0.005)\end{array}$ & $\begin{array}{l}0.020^{* * *} \\
(0.004)\end{array}$ & $\begin{array}{c}0.007^{*} \\
(0.003)\end{array}$ & $\begin{array}{l}0.136^{* * *} \\
(0.004)\end{array}$ & $\begin{array}{l}0.076^{* * *} \\
(0.004)\end{array}$ & $\begin{array}{l}0.085^{* * *} \\
(0.004)\end{array}$ & $\begin{array}{l}0.073^{* * *} \\
(0.004)\end{array}$ & $\begin{array}{l}0.066^{* * *} \\
(0.004)\end{array}$ \\
\hline$\%$ Vacant housing & $\begin{array}{c}0.009^{* *} \\
(0.003)\end{array}$ & $\begin{array}{l}0.016^{* * *} \\
(0.003)\end{array}$ & $\begin{array}{c}-0.008^{* *} \\
(0.003)\end{array}$ & $\begin{array}{l}0.028^{* * *} \\
(0.003)\end{array}$ & $\begin{array}{c}-0.030^{* * *} \\
(0.003)\end{array}$ & $\begin{array}{c}-0.012^{* * *} \\
(0.003)\end{array}$ & $\begin{array}{c}-0.007^{*} \\
(0.003)\end{array}$ & $\begin{array}{c}-0.011^{* * *} \\
(0.003)\end{array}$ \\
\hline W \% Vacant housing & $\begin{array}{c}0.010^{*} \\
(0.005)\end{array}$ & $\begin{array}{c}0.005 \\
(0.004)\end{array}$ & $\begin{array}{c}-0.040^{* * *} \\
(0.003)\end{array}$ & $\begin{array}{l}0.078^{* * *} \\
(0.004)\end{array}$ & $\begin{array}{c}-0.083^{* * *} \\
(0.004)\end{array}$ & $\begin{array}{c}-0.045^{* * *} \\
(0.004)\end{array}$ & $\begin{array}{c}-0.020^{* * *} \\
(0.004)\end{array}$ & $\begin{array}{c}-0.042^{* * *} \\
(0.004)\end{array}$ \\
\hline Living space & $\begin{array}{c}-0.034^{* * *} \\
(0.004)\end{array}$ & $\begin{array}{c}-0.039^{* * *} \\
(0.003)\end{array}$ & $\begin{array}{l}0.011^{* * *} \\
(0.003)\end{array}$ & $\begin{array}{c}-0.051^{* * *} \\
(0.003)\end{array}$ & $\begin{array}{c}-0.084^{* * *} \\
(0.003)\end{array}$ & $\begin{array}{c}-0.092^{* * *} \\
(0.003)\end{array}$ & $\begin{array}{c}-0.044^{* * *} \\
(0.003)\end{array}$ & $\begin{array}{c}-0.050^{* * *} \\
(0.003)\end{array}$ \\
\hline W Living space & $\begin{array}{c}-0.076^{* * *} \\
(0.005)\end{array}$ & $\begin{array}{c}-0.069^{* * *} \\
(0.004)\end{array}$ & $\begin{array}{l}0.025^{* * *} \\
(0.003)\end{array}$ & $\begin{array}{c}-0.125^{* * *} \\
(0.004)\end{array}$ & $\begin{array}{c}-0.172^{* * *} \\
(0.004)\end{array}$ & $\begin{array}{c}-0.200^{* * *} \\
(0.004)\end{array}$ & $\begin{array}{c}-0.095^{* * *} \\
(0.004)\end{array}$ & $\begin{array}{c}-0.108^{* * *} \\
(0.004)\end{array}$ \\
\hline City $(\geq 100,000)$ & $\begin{array}{l}0.245^{* * *} \\
(0.013)\end{array}$ & $\begin{array}{l}0.379^{* * *} \\
(0.012)\end{array}$ & $\begin{array}{l}0.883^{* * *} \\
(0.010)\end{array}$ & $\begin{array}{c}-0.378^{* * *} \\
(0.013)\end{array}$ & $\begin{array}{l}0.723^{* * *} \\
(0.012)\end{array}$ & $\begin{array}{l}0.810^{* * *} \\
(0.012)\end{array}$ & $\begin{array}{l}1.005^{* * *} \\
(0.012)\end{array}$ & $\begin{array}{l}1.076^{* * *} \\
(0.010)\end{array}$ \\
\hline $\mathrm{R}^{2}$ & 0.032 & 0.173 & 0.460 & 0.123 & 0.203 & 0.262 & 0.253 & 0.411 \\
\hline Adj. R & 0.032 & 0.173 & 0.460 & 0.123 & 0.203 & 0.262 & 0.253 & 0.411 \\
\hline Num. obs. & 93777 & $777 \quad 9$ & $777 \quad 93$ & 777 & 3777 & 7777 & 777 & 777 \\
\hline
\end{tabular}

${ }^{* * *} p<0.001,{ }^{* *} p<0.01,{ }^{*} p<0.05$. All variables are standardized expect of city dummy. Standard errors in parentheses. $\mathrm{W}$ is spezified as row-normalized contiguity weights matrix. E-PRTR: toxicity weighted air pollution of industrial facilities; Prox: proximity to nearest E-PRTR facility. Index: mean of NO2, PM10, PM2.5, SO2. 
Table A2. Municipality-fixed effects SLX models.

\begin{tabular}{|c|c|c|c|c|c|c|c|c|}
\hline & $\begin{array}{c}\text { E-PRTR } \\
(1)\end{array}$ & $\begin{array}{c}\text { Prox } \\
(2)\end{array}$ & $\begin{array}{c}\text { NO2 } \\
(3)\end{array}$ & $\begin{array}{l}\text { O3 } \\
(4)\end{array}$ & $\begin{array}{l}\text { PM10 } \\
(5)\end{array}$ & $\begin{array}{c}\text { PM2.5 } \\
\text { (6) }\end{array}$ & $\begin{array}{c}\text { SO2 } \\
(7)\end{array}$ & $\begin{array}{c}\text { Index } \\
(8)\end{array}$ \\
\hline \% Foreigners & $\begin{array}{l}0.061^{* * *} \\
(0.009)\end{array}$ & $\begin{array}{l}0.131^{* * *} \\
(0.009)\end{array}$ & $\begin{array}{l}0.037^{* * *} \\
(0.003)\end{array}$ & $\begin{array}{c}-0.008^{* * *} \\
(0.002)\end{array}$ & $\begin{array}{l}0.048^{* * *} \\
(0.002)\end{array}$ & $\begin{array}{l}0.026^{* * *} \\
(0.002)\end{array}$ & $\begin{array}{l}0.029^{* * *} \\
(0.003)\end{array}$ & $\begin{array}{l}0.037^{* * *} \\
(0.002)\end{array}$ \\
\hline W \% Foreigners & $\begin{array}{l}0.166^{* * *} \\
(0.026)\end{array}$ & $\begin{array}{l}0.217^{* * *} \\
(0.017)\end{array}$ & $\begin{array}{l}0.099^{* * *} \\
(0.013)\end{array}$ & $\begin{array}{c}-0.035^{* * *} \\
(0.007)\end{array}$ & $\begin{array}{l}0.112^{* * *} \\
(0.007)\end{array}$ & $\begin{array}{l}0.061^{* * *} \\
(0.006)\end{array}$ & $\begin{array}{l}0.067^{* * *} \\
(0.009)\end{array}$ & $\begin{array}{l}0.091^{* * *} \\
(0.008)\end{array}$ \\
\hline Population & $\begin{array}{c}-0.010 \\
(0.007)\end{array}$ & $\begin{array}{c}-0.044^{* * *} \\
(0.009)\end{array}$ & $\begin{array}{l}0.018^{* * *} \\
(0.003)\end{array}$ & $\begin{array}{c}0.032^{* * *} \\
(0.006)\end{array}$ & $\begin{array}{l}0.016^{* * *} \\
(0.003)\end{array}$ & $\begin{array}{l}0.027^{* * *} \\
(0.003)\end{array}$ & $\begin{array}{l}0.036^{* * *} \\
(0.004)\end{array}$ & $\begin{array}{l}0.032^{\text {*** }} \\
(0.003)\end{array}$ \\
\hline W Population & $\begin{array}{c}-0.040 \\
(0.023)\end{array}$ & $\begin{array}{l}0.078^{* * *} \\
(0.013)\end{array}$ & $\begin{array}{l}0.102^{* * *} \\
(0.011)\end{array}$ & $\begin{array}{l}0.061^{* *} \\
(0.022)\end{array}$ & $\begin{array}{l}0.092^{* * *} \\
(0.011)\end{array}$ & $\begin{array}{l}0.101^{* * *} \\
(0.006)\end{array}$ & $\begin{array}{l}0.113^{* * *} \\
(0.010)\end{array}$ & $\begin{array}{l}0.126^{* * *} \\
(0.006)\end{array}$ \\
\hline$\% 65$ and older & $\begin{array}{c}-0.005 \\
(0.004)\end{array}$ & $\begin{array}{c}0.004 \\
(0.002)\end{array}$ & $\begin{array}{c}0.002 \\
(0.001)\end{array}$ & $\begin{array}{l}0.013^{* * *} \\
(0.002)\end{array}$ & $\begin{array}{c}0.001 \\
(0.001)\end{array}$ & $\begin{array}{c}0.001 \\
(0.001)\end{array}$ & $\begin{array}{c}0.002^{*} \\
(0.001)\end{array}$ & $\begin{array}{c}0.002^{* *} \\
(0.001)\end{array}$ \\
\hline W \% 65 and older & $\begin{array}{c}-0.008 \\
(0.007)\end{array}$ & $\begin{array}{c}0.006 \\
(0.004)\end{array}$ & $\begin{array}{c}-0.000 \\
(0.003)\end{array}$ & $\begin{array}{l}0.023^{* * *} \\
(0.004)\end{array}$ & $\begin{array}{c}-0.001 \\
(0.002)\end{array}$ & $\begin{array}{c}-0.001 \\
(0.001)\end{array}$ & $\begin{array}{c}0.001 \\
(0.002)\end{array}$ & $\begin{array}{c}-0.000 \\
(0.002)\end{array}$ \\
\hline$\%$ Vacant housing & $\begin{array}{c}0.014^{* *} \\
(0.005)\end{array}$ & $\begin{array}{l}0.016^{* * *} \\
(0.003)\end{array}$ & $\begin{array}{c}-0.001 \\
(0.001)\end{array}$ & $\begin{array}{l}0.008^{* * *} \\
(0.002)\end{array}$ & $\begin{array}{c}0.001 \\
(0.001)\end{array}$ & $\begin{array}{c}-0.000 \\
(0.001)\end{array}$ & $\begin{array}{c}0.003^{*} \\
(0.001)\end{array}$ & $\begin{array}{c}0.001 \\
(0.001)\end{array}$ \\
\hline W \% Vacant housing & $\begin{array}{c}0.020^{*} \\
(0.008)\end{array}$ & $\begin{array}{c}0.010 \\
(0.005)\end{array}$ & $\begin{array}{c}-0.014^{* * *} \\
(0.002)\end{array}$ & $\begin{array}{l}0.021^{* * *} \\
(0.004)\end{array}$ & $\begin{array}{c}-0.011^{* * *} \\
(0.002)\end{array}$ & $\begin{array}{c}-0.010^{* * *} \\
(0.002)\end{array}$ & $\begin{array}{c}-0.003 \\
(0.003)\end{array}$ & $\begin{array}{c}-0.011^{* * *} \\
(0.002)\end{array}$ \\
\hline Living space & $\begin{array}{c}-0.012^{* *} \\
(0.004)\end{array}$ & $\begin{array}{c}-0.036^{* * *} \\
(0.004)\end{array}$ & $\begin{array}{c}-0.008^{* * *} \\
(0.001)\end{array}$ & $\begin{array}{c}0.002 \\
(0.003)\end{array}$ & $\begin{array}{c}-0.013^{* * *} \\
(0.002)\end{array}$ & $\begin{array}{c}-0.008^{* * *} \\
(0.002)\end{array}$ & $\begin{array}{c}-0.009^{* * *} \\
(0.002)\end{array}$ & $\begin{array}{l}-0.010^{* * *} \\
(0.002)\end{array}$ \\
\hline W Living space & $\begin{array}{c}-0.036^{* * *} \\
(0.007)\end{array}$ & $\begin{array}{c}-0.064^{* * *} \\
(0.007)\end{array}$ & $\begin{array}{c}-0.015^{* * *} \\
(0.003)\end{array}$ & $\begin{array}{c}0.001 \\
(0.005) \\
\end{array}$ & $\begin{array}{c}-0.023^{* * *} \\
(0.004)\end{array}$ & $\begin{array}{c}-0.015^{* * *} \\
(0.004)\end{array}$ & $\begin{array}{c}-0.018^{* * *} \\
(0.004)\end{array}$ & $\begin{array}{c}-0.019^{* * *} \\
(0.003) \\
\end{array}$ \\
\hline $\mathrm{R}^{2}$ & 0.019 & 0.069 & 0.197 & 0.030 & 0.244 & 0.300 & 0.216 & 0.309 \\
\hline Adj. $R^{2}$ & -0.031 & 0.022 & 0.157 & -0.019 & 0.206 & 0.265 & 0.176 & 0.274 \\
\hline Num. obs. & 93777 & & & $3777 \quad 93$ & & $3777 \quad 93$ & 777 & 3777 \\
\hline
\end{tabular}

${ }^{* * *} p<0.001,{ }^{* *} p<0.01,{ }^{*} p<0.05$. All variables are standardized expect of city dummy. Cluster-robust standard errors (municipality level) in parentheses. W is spezified as row-normalized contiguity weights matrix. E-PRTR: toxicity weighted air pollution of industrial facilities; Prox: proximity to nearest E-PRTR facility. Index: mean of NO2, PM10, PM2.5, SO2. 